\title{
TRANSLATION PECULIARITIES IN OIL AND GAS INDUSTRY
}

\author{
Lilia Timofeeva, Tamara Potapova
}

\author{
St. Petersburg State University, School of Foreign Languages, Department of the English Language for \\ Business and Law \\ E-mail: lilytimofeyeva@yahoo.com; tamara.potapova2010@yandex.ru
}

\begin{abstract}
The article focuses on the actual issues of translation problems in the oil and gas industry, in particular on finding adequate equivalents to highly technical terms in both languages, the translation of abbreviations and the application of technical normative documentation $\left(G O S T^{l}\right)$. The research is based on the engineering documents developed in English and Russian for the major oil and gas projects to be implemented in Russia 2006-2009.
\end{abstract}

Key words: highly technical terms, abbreviations, oil and gas industry, translation

\section{INTRODUCTION}

Being an international business, oil and gas industry enjoys the major part of projects conducted in Russia. Thus, for successful cooperation and implementation of projects there is an urgent need for high quality written and oral translation of the materials connected with this sphere; it also provides stable demand for translation of different kinds of documents in oil and gas industry, including, for example, tender documentation, process flow diagrams, process descriptions, drawings, capacity summaries, fuel balances, inspection reports, material requisitions, and thousands of other documents which constitute the project documentation. A translator in oil and gas industry should possess not only well developed language skills, know methodology and principles of translation in the field of science and technology, but should also be fully aware of how a particular technological sphere works.

The aim of this article is to show the difficulties a translator may face working in the field of oil and gas industry and discuss possible solutions they may undertake. The authors also revise the existing approaches to dealing with highly technical terminology.

\section{CORPORATE GLOSSARIES IN OIL AND GAS INDUSTRY}

Highly professional terminology of oil and gas industry is very difficult for translation. Firstly, for high quality translation one needs extensive vocabulary, secondly, the existing dictionaries reflect specifics of the technical terminology not always correctly. Sometimes they just cannot catch up with quick development of existing technologies and emergence of the new ones.

\footnotetext{
Submitted October $3^{\text {rd }}, 2019$, accepted for publication November $3^{\text {rd }}, 2019$

${ }^{1}$ Russian National Standard 
Modern companies of the international level fully understand that coherence in terminology provides comprehension and are engaged in working with terms, clarifying those which may lead to misunderstanding, ensuring unification of terminology used. They are working out special terminological databases, which contain not only highly professional terms, specific for this particular industry, but also corporative word reductions and in-house terminology, which appear not common.

Thus, the websites of such companies as GAZPROM ${ }^{2}$ and $\mathrm{LUKOIL}^{3}$ provide glossaries, which, catering for English speaking readers, explain and comment on abbreviations used in companies, starting with those generally used, such as APG that can be found in specialized dictionaries or specially invented by the company, e.g. ORP (oil refinery plant), usually presented in English texts as REFINERY, or the terms connected with Russian reality.

Let us give some examples:

Table 1 Terms from corporate glossaries

\begin{tabular}{|c|c|c|}
\hline English & Russian & Transliteration \\
\hline $\begin{array}{l}\text { APG (Associated } \\
\text { Petroleum Gas) }\end{array}$ & $\begin{array}{l}\text { ПНГ (попутный нефтяной } \\
\text { газ) }\end{array}$ & $\begin{array}{l}\text { PNG [poputniy neftyanoy } \\
\text { gaz] }\end{array}$ \\
\hline $\begin{array}{l}\text { EMERCOM (the Ministry } \\
\text { of the Russian Federation } \\
\text { for Civil Defense, } \\
\text { Emergencies and } \\
\text { Elimination of } \\
\text { Consequences of Natural } \\
\text { Disasters) }\end{array}$ & $\begin{array}{l}\text { Министерство Российской } \\
\text { Федерации по делам } \\
\text { гражданской обороны, } \\
\text { чрезвычайным ситуациям и } \\
\text { ликвидации последствий } \\
\text { стихийных бедствий }\end{array}$ & $\begin{array}{l}\text { Ministerstvo Rossijskoy } \\
\text { Federatsii po delam } \\
\text { grazhdanskoy oboroni, } \\
\text { chrezvichajnim situatsiyam I } \\
\text { likvidatsii posledstviy } \\
\text { stikhiinikh bedstviy }\end{array}$ \\
\hline $\begin{array}{l}\text { CGTP (Complex Gas } \\
\text { Treatment Plant) }\end{array}$ & $\begin{array}{l}\text { УКПГ (установка } \\
\text { комплексной подготовки газа) }\end{array}$ & $\begin{array}{l}\text { UKPG [ustanovka } \\
\text { kompleksnoy podgotovki } \\
\text { gaza] }\end{array}$ \\
\hline ORP (oil refinery plant) & $\begin{array}{l}\text { НПЗ } \\
\text { (нефтеперерабатывающий } \\
\text { завод) }\end{array}$ & $\begin{array}{l}\text { NPZ } \\
\text { [neftepererabatyvayuschi } \\
\text { zavod] }\end{array}$ \\
\hline
\end{tabular}

Unfortunately, Lukoil closed access to English-Russian glossary of terms, which were presented on their website in 2006-2008.

Another difficulty is connected with the fact that even generally known abbreviations cannot be always found in standard English - English online dictionaries (Webster ${ }^{4}$, Cambridge ${ }^{5}$, Oxford $^{6}$ ), but fortunately, they can be found in English-Russian dictionaries, though not each one. In such cases translators have to search for the meaning themselves, with possible help of technical specialists (if available), tender documentation (if a

\footnotetext{
${ }^{2}$ http://gazprom-neft.com/\#company-today

${ }^{3}$ http://lukoil.ru

${ }^{4}$ https://www.merriam-webster.com

${ }^{5} \mathrm{https}: / /$ dictionary.cambridge.org/ru

${ }^{6} \mathrm{https}$ ://en.oxforddictionaries.com
} 
translator has access to it), the Internet (some useful links are provided in the references), translators forums, etc.

\section{TERMS AND TERMINOLOGY}

So, main problems in translation are connected either with industry terms, used in one sphere of knowledge, or highly professional terms, typical for a certain sector of industry. According to V.N. Komissarov (Komissarov, 1990) terms are "words and word combinations denoting specific objects and notions that are exploited by specialists in a certain field of science and technology". A. A. Reformatskiy (Reformatskiy, 2001) denotes terms as "monosemantic words that lack expressiveness". S. B. Grinev - Grinevich (Grinev - Grinevich, 2008) characterizes terms as "special nominative lexical units (a word or word combination) of a special language, used for exact nomination of special notions". V. A. Tatarinov (Tatarinov, 2000) thinks that "we cannot speak about monosemic structure of a term or about one-to-one correspondence (isomorphism) - "one term-one notion", just because of simple development of notions and categories..."

The basis of introduction and exploitation of a term is the agreement between people on the meaning of this term. If such agreement does not exist, misunderstanding may occur. Inconsistent and wrong use of the terms, substitution of one term by another lead to distortion of the initial information and hinder communication.

To avoid such problems in the beginning of the project, and sometimes even on the stage of preparation of tender documentation, at least a short list of abbreviations to be sent to technical specialists and translators to ensure uniformity of terminology used in the project. But it should be compiled according to the Recommendations of $\mathrm{SPR}^{7}$, which enables to find typical solutions of problems a translator may face, namely Specific Terminology.

While translating technical texts we may recommend to use terms, prescribed by corresponding state terminological standards, or terms contained in terminological supplements to state standards; the above mentioned missing, the terms from the compendium of recommended terms by the Committee of scientific-technological terminology of the Russian Academy of Science, or similar documents. If the glossary or other informational or reference materials are not provided by the customer, translators should base their translation only on their own experience and knowledge.

\subsection{Abbreviation nightmare}

Oil and gas translation deals with a myriad of abbreviations, which are widely used and could be a nightmare for a translator. Here is just one example: "At TBT it was discussed that BHA will be RIH with slower ROP that was indicated in the JSA" (Belonogova, 2019). The thing is that in most cases oil and gas equipment, processes, technical documentation, possess the full and short names. It seems that abbreviations help saving time, yet are tricky.

\footnotetext{
${ }^{7}$ https://translators-union.ru

${ }^{8}$ The example is taken from the article published http://www.toptr.ru/library/translation-truth/neftegazovyieabbreviaturyi.-vvedenie-v-predmet.html?fbclid=IwAR3SXD_I0BKnbt1 A0rR5RFYoqVn7ODAHtq9RAPZrPS9FbRvcDI45qH8zAs
} 
While translating, one should try not to use transliteration in the process of conveying abbreviation as it may lead to misunderstanding of the text. For example in the sentence “Отбор проб без остановки скважины и изменения ЭРРС” [Otbor prob bez ostanovki skvazhini I izmeneniya ERRS], one cannot use transliteration in translating of abbreviation ЭРРС, as this abbreviation means ЭКСПЛУАТАЦИОННЫЙ РЕЖИМ РАБОТЫ СКВАЖИНЫ (eksplutatsionnii rezhim raboti skvazhini) and is translated into English as WELL OPERATION, but not ERRS, which has no meaning. Let see some examples ${ }^{9}$ :

Table 2 Abbreviations

\begin{tabular}{|c|c|c|c|c|}
\hline \multicolumn{2}{|c|}{ English } & \multicolumn{2}{|r|}{ Russian } & \multirow[t]{2}{*}{ Transliteration } \\
\hline Abbrevi & Definition & Abbreviation & Definition & \\
\hline $\mathrm{AGO}$ & $\begin{array}{l}\text { Atmospheric } \\
\text { gasoil }\end{array}$ & $\mathrm{A} \Gamma$ & $\begin{array}{l}\text { Атмосферный } \\
\text { газойль }\end{array}$ & Atmosfernii gazoil' \\
\hline HHGO & $\begin{array}{l}\text { Heavy heavy } \\
\text { gasoil }\end{array}$ & СТГ & $\begin{array}{l}\text { Сверхтяжелый } \\
\text { газойль }\end{array}$ & Svekhtyazhelii gazoil' \\
\hline LGO & Light gasoil & ЛГ & $\begin{array}{l}\text { Легкий } \\
\text { атмосферный } \\
\text { газойль }\end{array}$ & $\begin{array}{l}\text { Legkii atmosfernii } \\
\text { gazoil' }\end{array}$ \\
\hline $\mathrm{HGO}$ & Heavy gasoil & $\mathrm{T} \Gamma$ & $\begin{array}{l}\text { Тяжелый } \\
\text { атмосферный } \\
\text { газойль }\end{array}$ & $\begin{array}{l}\text { Tyazhelii atmosfernii } \\
\text { gazoil' }\end{array}$ \\
\hline VGO & Vacuum gasoil & $\mathrm{B} \Gamma$ & $\begin{array}{l}\text { Вакуумный } \\
\text { газойль }\end{array}$ & Vakuumnii gazoil’' \\
\hline LVGO & $\begin{array}{l}\text { Light vacuum } \\
\text { gasoil }\end{array}$ & ЛВГ & $\begin{array}{l}\text { Легкий вакуумный } \\
\text { газойль }\end{array}$ & $\begin{array}{l}\text { Legkhii vakuumnii } \\
\text { gazoil' }\end{array}$ \\
\hline MVGO & $\begin{array}{l}\text { Medium } \\
\text { vacuum gasoil }\end{array}$ & $\mathrm{CB \Gamma}$ & $\begin{array}{l}\text { Средний } \\
\text { вакуумный } \\
\text { газойль }\end{array}$ & $\begin{array}{l}\text { Srednii vakuumnii } \\
\text { gazoil' }\end{array}$ \\
\hline HVGO & $\begin{array}{l}\text { Heavy vacuum } \\
\text { gasoil }\end{array}$ & TBГ & $\begin{array}{l}\text { Тяжелый } \\
\text { вакуумный газойль }\end{array}$ & $\begin{array}{l}\text { Tyazhelii vakuumnii } \\
\text { gazoil' }\end{array}$ \\
\hline AR & $\begin{array}{l}\text { Atmospheric } \\
\text { residue }\end{array}$ & |----------- & Мазут* & Mazut \\
\hline VR & $\begin{array}{l}\text { Vacuum } \\
\text { residue }\end{array}$ & |----------- & Гудрон & Gudron \\
\hline ------- & Desalter & ЭДГ & Электродегидратор & Elektrodegidrator \\
\hline ----- & $\begin{array}{l}\text { Vacuum } \\
\text { package }\end{array}$ & $\mathrm{BCC}$ & $\begin{array}{l}\text { Вакуумсоздающая } \\
\text { система }\end{array}$ & $\begin{array}{l}\text { Vakuumsozdayuschaya } \\
\text { sistema }\end{array}$ \\
\hline
\end{tabular}

* When it is a product, it is translated as fuel oil.

As we can see from the example, the abbreviations are constructed from the first letters of words of each language, and if neither language possesses generally accepted

\footnotetext{
${ }^{9}$ Unless otherwise specified, all examples are taken from project documentation of TECHNIP RUS company where one of the authors worked from 2005 to 2009.
} 
abbreviations, as in case of the terms MAZUT and DESALTER, the abbreviation calques are not formed, and the full form of the word is used.

Typically in the English language the shortening of a unit ends on U (unit - установка (ustanovka), as the nominative attributive group is in pre-position to the main word, while in the Russian language the word group starts with the word установка [ustanovka] (the main word) and the dependent words are in post-position in genitive case, thus, naturally, the first letter in abbreviation will be $\mathrm{Y}[\mathrm{U}]$.

As it was mentioned above, a part of abbreviations are in general use and are repeated in the very project, irrespective from the customer, as UKPG (установка комплексной подготовки газа [ustanovka kompleksnoi podgotovki gaza]) in Russian and GTP (gas treatment plant) in English, BFW (Boiler Feed Water) and KTV (котловая вода [kotlovaya voda]), at the same time abbreviations remain in the name of technological equipment and appear both on the process flow diagrams and in the description of technological process.

BFW Cooler (холодильник КТВ [kholodil'nik KTV]), BFW Pumps (насосы КТВ [nasosi KTV]), a part is coined during translation, so SDA (Solvent Deasphalting Unit) becomes ДАР [DAR] (установка деасфальтизации растворителем [ustanovka deasfaltizatsii rastvoritelem] by agreement with the customer, and DRU (Diluent Recovery Unit) means УBP [UVR] (установка выделения разбавителя [ustanovka videleniya razbavitelya]).

\subsection{Collaboration of the languages}

Another difficulty is connected with the fact, that depending on the process technology, one and the same word in the Russian language can be translated into English in a different way.

Table 3 Comparison of English and Russian terms

\begin{tabular}{|c|c|c|}
\hline Russian & English & Transliteration \\
\hline ХОЛОДИЛЬНИК ПИРОГАЗА & CRACKED GAS CHILLER & kholodil'nik pirogaza \\
\hline $\begin{array}{l}\text { ХОЛОДИЛЬНИК } \\
\text { ГИДРИРОВАНИЯ ЭЭФ }\end{array}$ & $\mathrm{C}_{2}$ HYDROGENATION COOLER & $\begin{array}{l}\text { kholoil'nik gidrirovaniya } \\
\text { eef }\end{array}$ \\
\hline $\begin{array}{l}\text { ХОЛОДИЛЬНИК } \\
\text { ХЛАДАГЕНТА ЭТИЛЕНА }\end{array}$ & $\begin{array}{l}\text { ETHYLENE REFRIGERANT } \\
\text { DESUPERHEATER }\end{array}$ & $\begin{array}{l}\text { kholodil'nik khladagenta } \\
\text { etilena }\end{array}$ \\
\hline $\begin{array}{l}\text { АВО (АППАРАТ } \\
\text { ВОЗДУШНОГО } \\
\text { ОХЛАЖДЕНИЯ) }\end{array}$ & AIR COOLER & $\begin{array}{l}\text { apparat vozdushnogo } \\
\text { okhlazhdenya }\end{array}$ \\
\hline ПЕЧЬ ДОЖИГА & INCINERATOR & pech' dozhiga \\
\hline ПЕЧЬ ПИРОЛИЗА & CRACKING FURNACE & pech' piroliza \\
\hline ВАКУУМНАЯ ПЕЧЬ & VACUUM HEATER & vakuumnaya pech' \\
\hline
\end{tabular}

The same can be witnessed in the case of the term ЕМКОСТЬ [emkost], which can be translated into English at least with three synonyms - DRUM, VESSEL, TANK, at the same time each of them can have its own translation: DRUM- EMKOCTb [emkost], 
VESSEL- СОСУД [sosud], TANK - PE3ЕРВУАР [reservuar], and all of them refer to ЕМКОСТНОЕ ОБОРУДОВАНИЕ [emkostnoye oborudovanie] - an official term in regulatory and technical documentation. At the same time KO DRUM can be translated both as (КАПЛЕОТБОЙНАЯ ЕМКОСТЬ [kapleotbojnaya emkost] and (СЕПАРАТОР [separator]), though specialists are sure that both terms are suitable and the choice depends on the preferences of the translator. Such variety in both languages makes a translator study the process description and learn to read drawings.
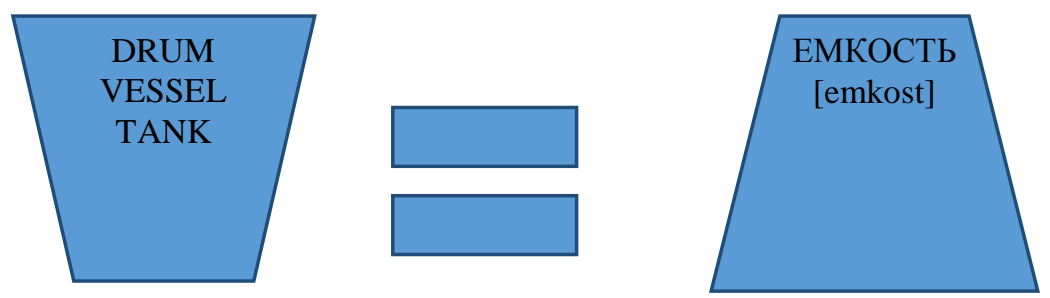

DRUM- ЕМКОСТЬ [emkost], VESSEL- СОСУД [sosud], TANK - PE3EPBУAP [reservuar],

ЕМКОСТНОЕ ОБОРУДОВАНИЕ

[emkostnoye oborudovanie]

Fig. 1 Comparison of English and Russian terms

Together with the emergence of new technologies and new methods of oil production and processing and refusal from outdated methods and equipment terminology in the sphere of oil and gas industry is constantly renewed. Foreign borrowings are included into the term system, and for a while both terms are being equally used: e.g. ИНСИНЕРАТОР [insinerator] and ПЕЧЬ ДОЖИГА [pech' dozhiga], РЕБОЙЛЕР [reboiler] and ПОДОГРЕВАТЕЛЬ/ КИПЯТИЛЬНИК [podogrevatel'/kipyatil'nik]. The term РЕБОЙЛЕР [reboiler] has gradually won over the term КИПЯТИЛЬНИК [kipyatil'nik] $]^{10}$, which can be traced in technical literature, as for example "Справочник химика 21 "'11 we find ПОДОГРЕВАТЕЛЬ - РЕБОЙЛЕР [podogrevatel'- reboiler], in the article of V.V. KALLUS, published in the journal "Химическая техника"12 we may see РЕБОЙЛЕР-КИПЯТИЛЬНИК/ ИСПАРИТЕЛЬ [reboiler-kipyatil'nik/isparitel]. However, at the same time, normative documentation does not include this term. It looks like the term КИПЯТИЛЬНИК РЕКТИФИКАЦИОННОЙ КОЛОННЫ [kipyatil'nik rektifikatsionnoj kolonni] sounds old fashioned, БОКОВОЙ ОДОГРЕВАТЕЛЬ РЕКТИФИКАЦИОННОЙ КОЛОННЫ [bokovoj podogrevatyal' rektifikatsionnoj kolonni] sounds not modern, but the word combination with the borrowed word РЕБОЙЛЕР РЕКТИФИКАЦИОННОЙ КОЛОННЫ [reboiler rektifikatsionnoj kolonni] reflects modern technologies. From the point of view of a translator, it definitely makes the very process of translation much easier. You do not need to search for a word or

\footnotetext{
${ }^{10}$ see Перри Дж. Справочник инженера-химика. 1969) - (Perry J. Reference-book of a chemical engineer. [Perry Dzh. Spravochnik inzhenera-khimika. Rus.]1969)

${ }^{11}$ Справочник химика 21 (Reference-book of a chemist 21. [“Spravochnik khimika 21"]. Rus.) (https://chem21.info/article/634835/

${ }_{12}^{12}$ Химическая техника, №7, 2018 (Chemical equipment [“Khimicheskaya tekhnika”] Rus.)
} 
remember the term in Russian, when you can say "сплитер нафты [spliter nafti]" instead of НАФТОПЕРЕГОННАЯ КОЛОННА [naftootgonnaya kolonna], "nечь крекинга [pech' krekinga]” instead of ПЕЧЬ ПИРОЛИЗА [pech' piroliza], “вакуумная дисцилляция [vakuumnaya distilyatsiya]" instead of ВАКУУМНАЯ ПЕРЕГОНКА [vakuumnaya peregonka], and there are many other examples of this kind. But there is one big problem - all project documentation is submitted to the authorities only in Russian and it should comply with the Russian normative technical standards. They are presented in a whole set of technical normative documentation ГОСТы (GOSTs), and first of all GOST 2.6012006 Unified system for design documentation. Exploitative documents., GOST R 2.901-99 Unified system for design documentation. Documentation to be sent abroad. General requirements. Definitely, specialists with technical education proofread the translation and make it comply with requirements, but the less correction the translation needs, the higher is the qualification of the translator, the more they are in demand on the labor market.

Another trap is Russification of the English language in the process of translation, by which we mean "translator's false friends". For example, in one of the proposals to participate in a tender that was sent to a foreign partner we read "with the localization of equipment, minimum 50\%". As the Russian part that was organizing the bidding sent all documentation already in English, translation seemed not to be needed, but the foreign partners were unable to understand this mysterious phrase. The context helped to understand that the Russian partner meant to place the order for equipment within the territory of Russian Federation, in a quantity not less than $50 \%$. And this is only one example of the situation, when translation from English into English is necessary.

One more interesting example is the usage of the word КОМПЛЕКС [compleks] in the Russian language and its translation into English in such word combinations as “газоперерабатывющий комплекс [gazoperebativajuschiy kompleks]”, “нефтехимический комплекс [neftekhimicheskiy kompleks] or "производственный комплекс [proizvodstvenniy kompleks]" which for foreign partners usually are "gas treatment plant", "petrochemical plant", "plant" respectively. But there is one drawback - in the process of translation the accordant lexical unit COMPLEX has been so often used improperly as in the documentation of the Russian customer, as on the English versions of Russian companies' cites during the last 10 years, that it has led to the fact, that even the native English speaking project developers themselves started to use this word combination in their own English language documentation - as in "gas treatment complex".

The research of the Internet resources has shown that the only one use of the word COMPLEX in such meaning that was recorded in the dictionary was in the word combination "military-industrial complex"13, but the international project Sakhalin -2 (Trefilova, 2009) uses the combination "Prigorodnoye production complex", and the cites of international companies are full of combinations based on the word COMPLEX - from "Innovation and Production Complex"14 to Pennsylvania Petrochemicals Complex" ${ }^{15}$, so it is quite possible that soon this new meaning would be recorded in the dictionaries.

\footnotetext{
${ }^{13}$ https://www.britannica.com

${ }^{14} \mathrm{https}: / /$ vertex.spb.ru/en/production/farmkompleks

${ }^{15}$ https://www.shell.com/about-us/major-projects
} 


\section{ANIMALS ON THE FIELD}

A special group of terms in oil and gas terminological system, which possess expressive coloring and serve as scientific-technological phraseological units, have been explored quite thoroughly. Quite a number of studies have been conducted on this topic. We can mention the works on the theory of terms by S.V. Grinev-Grinevich (GrinevGrinevich, 2008), D. S. Lotte (Lotte, 1982), A. V. Superanskaya (Superanskaya, 2012), A. V. Tatarinov (Tatarinov, 2000), and others. The majority of phraseological terms in oil and gas sphere are based on common features in appearance with corresponding animals (dog, snake, rabbit, cat, etc.). Thus, they are based on metaphor.

In the texts on oil and gas subject matter we may see such terms as:

- monkey board - площадка для верхового рабочего [ploschagka dlya verkhovogo rabochego];

- doghouse - вагончик-бытовка бурового мастера [vagonchik-bitovka burovogo mastera];

- rabbit / pig - скребок для чистки трубопровода [skrebok dlya chistki truboprovoda];

- wildcat - поисково-разведочная скважина [poiskovo-razvedochnaya skvazhina];

- snake - асбестовый шнур [asbestoviy shnur];

- pipe dog - трубный ключ [trubniy klyuch];

- butterfly valve - дисковой поворотный клапан [diskoviy povorotniy klapan].

\section{SPECIFICS OF TECHNICAL TEXTS}

Texts on science and technology possess many grammatical, lexical and stylistic peculiarities, which appear to be difficult for translators, as these texts cater for special professional groups, which possess specific extra-linguistic knowledge, and consequently require thorough analysis. Many characteristics of the style of science and technology can be traced in technical project documentation in both languages. According to V.N. Komissarov (Komissarov, 1990) the style of science and technology is characterized by:

- Highly informative content and abundance of terms and their descriptions;

- Standardized and coherent manner of narration;

- Nominative character of sentence construction;

- A great number of semi-terminological clichés;

- Predominance of verbs of Present tenses;

- Prevalence of compound sentences;

- Broad use of various means of logical connection.

At the same time a certain number of peculiarities of project documentation of oil and gas industry in the Russian language are connected with specific structures of the Russian language, they can be traced to special ways of application of these structures, compared to other styles of speech in Russian.

- Prevalence of nominative frame structures with the word order not relevant for other fields of science and technology, where a word group, which is clarifying the Participle or the Adjective play the role of a pre-positive Attribute (cf. “эксплуатируемые при низких температурах гибкие трубопроводы” “ekspluatiruemie pri nizkikh temperaturakh gibkie truboprovodi”); 
- Frequent use of short forms of adjectives (cf. (“Сборные гибкие трубопроводы очень удобны в эксплуатации" - “Sbornie gibkie truboprovodi ochen' udobni v ekspluatatsii");

- Frequent use of abstract Nouns (развитие (razvitie), решение (reshenie), процесс (process)).

Specific features of the English language are:

- Wide use of structures like "A is B", that is simple two-member sentences with a Compound Nominative Predicate, which consists of a link-verb and a Predicative (In fact the loss of Refinery fuel gas has little impact on GPP operation. The above expected characteristics are the ones occurring in Phase 1);

- Substitution of a verbal negation do not by a nominal non (particles are nonvolatile);

- Usage of Attributive groups (The above expected characteristics);

- Striving to nominalization of action processes (to do post-welding treatment);

- Substitution of Adverbs by a Noun-with-a- Preposition combination (with accuracy);

- Use of intensifying Adverbs in the role of the main modal and expressive means (considerably, essentially, significantly);

- Considerable predominance of Passive forms and Present Simple tense (In Configurations 1 and 2 an average of $17 \%$ and 23\%, respectively of hydrogen needs is imported from PETR);

- Wide use of elliptical constructions (e.g. with conjunctions whatever, if any);

- Substitution of Attributive Subordinate Clauses by Adjectives in post-position (with those units shutdowned...); or use of Infinitive in the function of an Attribute (the rate to be obtained).

\section{CONCLUSION}

The above presented examples, amusing ones included, show us how important the high professional level is for a translator of technical texts, how important it is to study special literature, to have access to high quality constantly renewed reference materials, to translate technical terminology adequately and follow all requirements imposed on the presentation of engineering design and technical specifications.

We cannot but agree with the idea that it is extremely important to continue the meticulous work in accumulating the experience of the translators working in the oil and gas sphere, storing the commentaries on applying the GOSTs in the process of technical translation, updating the existing and working out the new rules, which may facilitate high quality translation. 


\section{REFERENCES}

Белоногова Лина «Нефтегазовые аббревиатуры. Введение в предмет» Belonogova Lina, Oil and Gas Abbreviations. Introduction. [Neftegazovyie abbreviaturyi vvedenie v predmet. Rus.], 2019 http://www.toptr.ru/library/translation-truth/neftegazovyieabbreviaturyi.-vvedenie-v-predmet.html?fbclid=IwAR3SXD_I0BKnbt1A0rR5RFYoqVn7ODAHtq9RAPZrPS9FbRvcDI45qH8zAs

Гринев-Гриневич, С.В. Терминоведение : учеб. пособие для студ. высш. учеб. заведений. - М.: Издательский центр «Академия», 2008.- Grinev-Grinevich, S.V. Studies ob Terminology [Terminovedenie: ucheb. posobie dlya stud. vissh. ucheb. zavedeniy.Rus.] - M.: Izdatel'skiy tsentr «Akademiya», 2008.

Комиссаров, В.Н. Теория перевода (лингвистические аспекты) - М.: Высшая школа, 1990. - 253 c. - Komissarov, V.N. Theory of Translation (linguistic aspects) [Teoria perevoda (lingvisticheskie aspekti) Rus.]- M.: Visshaya shkola, 1990. - 253 s.

Лотте Д. С. Вопросы заимствования и упорядочения иноязычных терминов и терминоэлементов. М.: Наука, 1982. - Lotte, D.S. Questions of Borrowing and Streamlining of Foreign Language Terms and Terminological Elements [Voprosi zaimstvovaniua i uporyadochenya inoyazichnikh terminov i terminoelementov. Rus.] - M.: Nauka, 1982.

Реформатский, А.А. Введение в языковедение.- М.: Аспект-Пресс, 2001, 536 с. Refornatskiy, A.A. Introduction into Linguistics [Vvedenie v yazikovedenie Rus.]. M.: Aspekt-Press, 2001, $536 \mathrm{~s}$.

«Сахалин -2 глазами переводчика». Составитель: С.Д. Трефилова. М.: «Сахалин Энерджи Инвестмент Компани Лтд.», 2009. A Translator's Guide to Sakhalin-2. Compiled by S.D. Trefilova [Sakhalin-2 glazami perevodchika. Sostavitel': S.D. Trefilova.Rus. ] M.: "Sakhalin Energy Investment Company, Ltd. ”, 2009

Суперанская, А.В. Общая терминология: Вопросы теории / А.В. Суперанская, Н.В. Подольская, Н.В. Васильева / Отв. ред. Т.Л. Канделаки. Изд. 6-е. - М.: Книжный дом "ЛИБ-РОКОМ", 2012. - 248 с. Superanskaya A.V. General Terminology: Theoretical Issues [A.V. Superanskaya, N. V. Podolskaya, N. V. Vasil'eva/ Otv.red. T. L. Kandelaki. Izd.6-e. Rus.] - M.: Knizhniy dom "LIB-ROKOM”, 2012. - 248 s.

Татаринов, В.А. Теория терминоведения в 3-х т./ Т.1. Теория термина: история и современное состояние. - М.: Моск. Лицей, 2000. - 311 с..-Tatarinov, V. A. Theory of Terminology Studies. Theory of Terms. History and Contemporary State [Teoria terminovedenia $\mathrm{v}$ 3-kh t./ T. 1. Teoria termina: istoria I sovremennoye sostoyanie. Rus.] - M.: Mosk. Litsey,2000. - 311 s.

\section{STANDARDS AND REGULATORY DOCUMENTATION}

ПР 50.1.027-2014 Правила оказания переводческих и особых видов лингвистических услуг, Москва, Стандартинформ, 2014) (PR 50.1.027-2014 Regulations of providing translation and special linguistic services ["Pravila okazaniya perevodcheskikh i osobikh vidov lingvisticheskikh uslug” Rus.], Moskva, Standartinform. 2014).

ГОСТ 1.1-2002 "Межгосударственная система стандартизации. Термины и определения" (Interstate System for Standardization. Terms and definitions [mezhgosudarstvennaya sistema standartizatsii. Termini i opredelenya. Rus.]) 
ГОСТ 2.004-88 "Единая система конструкторской документации. Общие требования к выполнению конструкторских и технологических документов на печатающих и графических устройствах вывода ЭВМ" (Unified system for design documentation. General requirements for performing design and technological documentation on printing and graphical output devices of computers [Edinaya sistema konstruktorskoi dokumentatsii. Obshchie trebovaniya k vipolneniyu konstruktorskikh i tekhnologicheskikh dokumentov na pechatuyushch i graficheskikh ustroistvakh vivoda EVM, Rus.])

ГОСТ 2.601-2006 "Единая система конструкторской документации. Эксплуатационные документы" (Unified system for design documentation. Exploitative documents [Edinaya sistema konstruktorskoi dokumentatsii. Ekspluatatsionnie dokumenti. Rus.])

ГОСТ Р 2.901-99 "Единая система конструкторской документации. Документация, отправляемая за границу. Общие требования" (Unified system for design documentation. Documentation to be sent abroad. General requirements [Edinaya sistema konstruktorsoi dokumentatsii. Dokumentatsiya, otpravlyaemaya za granitsu. Obshhiye trebovanya. Rus.])

ГОСТ Р 7.0.3-2006 "Система стандартов по информации, библиотечному и издательскому делу. Издания. Основные элементы. Термины и определения". (System of standards on information, librarianship and publishing. Publications. Main elements. Terms and definitions [Sistema standartov po informatsii, bibliotechnomu i izdatel'skomu delu. Izdanya. Osnovnie elementi. Termini i opredelenya. Rus.])

ГОСТ 7.36-2006 "Система стандартов по информации, библиотечному и издательскому делу. Неопубликованный перевод. Общие требования и правила оформления" (System of standards on information, librarianship and publishing. Unpublished translation. General requirements and rules for typescript [Sistema standartov po informatsii, bibliotechnomu i izdatel'skomu delu. Neopublikovanii perevod. Obshchie trebovanya i pravila oformlenya. Rus.])

ГОСТ 7.79-2000 "Система стандартов по информации, библиотечному и издательскому делу. Правила транслитерации кирилловского письма латинским алфавитом" (System of standards on information, librarianship and publishing. Rules of transliteration of Cyrillic script by Latin alphabet [Sistema standartov po informatsii, bibliotechnomu i izdatel'skomu delu. Pravila transliteratsii kirillovskogo pis'ma latinskim alfavitob. Rus.])

ГОСТ 7.11-2004 "Система стандартов по информации, библиотечному и издательскому делу. Библиографическая запись. Сокращение слов и словосочетаний на иностранных европейских языках" (System of standards on information, librarianship and publishing. Bibliographic description and references. Rules for the abbreviation of words and word combinations in foreign European languages [Sistema standartov po informatsii, bibliotechnomu i izdatel'skomu delu. Bibliograficheskaya zapis'. Sokrashchenya slov i slovosochtanyi na inostrannikh evropeiskikh yazikakh. Rus.])

\section{ELECTRONIC RESOURCES}

http://www.neftepedia.ru/dir/

http://www.megapetroleum.ru/sokrashheniya-naimenovanij-v-neftyanoj-promyshlennosti/

http://oilgasinform.ru/science/glossary/

http://gazprom-neft.com/\#company-today

http://lukoil.ru

https://www.merriam-webster.com 
https://dictionary.cambridge.org/ru

https://en.oxforddictionaries.com

https://translators-union.ru

https://www.britannica.com

https://vertex.spb.ru/en/production/farmkompleks

https://www.shell.com/about-us/major-projects 